\title{
Tomasz Kalniuk
}

Uniwersytet Mikołaja Kopernika w Toruniu

tekantrop@umk.pl

ORCID: 0000-0002-2098-0160

\section{Swojscy obcy}

\section{The familiar Other}

\author{
Olga Zadurska, Naznaczeni od Pana Boga. Obcy wśród \\ swoich na wsi polskiej XIX i poczatku XX wieku, \\ Wydawnictwo Scholar, Warszawa 2021.
}

DOI: $10.12775 /$ LL.4.2021.009 | CC BY-ND 4.o

W nauce funkcjonują tematy wymagające i ryzykowne, tak ze względu na swą złożoność, jak i zasadniczość poruszanych kwestii. Na gruncie refleksji społecznej i humanistycznej bez wątpienia do takich należy tematyka obcości. Kanoniczne wieloaspektowe zagadnienie, szeroko dyskutowane i rozmaicie przedstawiane stanowi zarazem teren fascynujący, ale i nieprzyjazny, na którym łatwo się zagubić. W tradycyjnej taksonomii obcość sytuuje się w pobliżu śmierci i zaświatów, będących domeną baśniowych bohaterów w folklorze i specjalistów od sacrum w kulturze (Wróblewska 2011: 145-156; Zowczak 1991: 15-24). Już przed laty socjologowie i antropologowie kulturowi zwracali uwage na uniwersalność opozycji binarnej my-oni poprzedzonej dychotomią swój-obcy i związanej z nią ściśle klasyfikacji osób na ludzi i nieludzi. Leżące u podstaw etnologii: rejestracja, opis i analiza odmienności doczekały się w przeciągu ponad stulecia (licząc od formalnego zawiązania się dyscypliny) licznych publikacji. Naznaczeni od Pana Boga. Obcy wśród swoich na wsi polskiej XIX i początku XX wieku Olgi Zadurskiej dołączają do tego bogatego księgozbioru.

Napisanie monografii o tak fundamentalnej tematyce, która była wcześniej podejmowana $\mathrm{w}$ pracach sygnowanych nazwiskami ważnych badaczy, mogłoby 
onieśmielać niejednego. Autorka znajduje jednak własne miejsce w nurcie rozważań nad ludową obcością, poszukując obcych wśród swoich. Liczne dostępne publikacje, do których Zadurska odnosi się merytorycznie i z szacunkiem, nie wywołują w jej wywodzie fragmentaryczności i wielowątkowej chaotyczności, lecz stają się pomocą i naświetlają rozważania autorki z różnych perspektyw. Równowaga badawcza i warsztatowy profesjonalizm oszczędzają odbiorcy czytelniczego dyskomfortu. Rozpoznanie tematu w źródłach i dotychczasowych opracowaniach, umiejętnie wplecione w autorską refleksję, zapewnia komfortową recepcję pracy. W efekcie czytelnik otrzymuje logicznie skonstruowaną i dobrze napisaną książkę naukową, choć trzeba dodać, że w niektórych jej fragmentach harmonię stylu zaburzają zdania wielokrotnie złożone, które lepiej byłoby uprościć.

Autorka Naznaczonych od Pana Boga wychodząc od socjologicznych uniwersaliów dotyczących mechanizmów kategoryzacji i stygmatyzacji społecznej, przygląda się im w kontekście etnograficznego konkretu. W oparciu o umiejętnie zgromadzony bogaty materiał folklorystyczny opisuje funkcjonowanie obcych wśród swoich w konkretnej rzeczywistości polskiej kultury ludowej XIX i początku XX w. Autorkę interesuje więc taki rodzaj obcych, którzy są wewnętrzni, nie etniczni, a tym samym jakby „mniej obcy”, i których słusznie uznaje za niezbywalny i funkcjonalny element tradycyjnego świata, zapewniający mu samoidentyfikację $e^{1}$ Zestawiony przez Zadurską katalog tak pojmowanych obcych jest niejednorodny, zawiera w sobie przedstawicieli różnych grup społecznych i zawodowych. Autorka ma świadomość dokonania arbitralnego cięcia przy takim doborze bohaterów swojej pracy (s. 19). Zdaje sobie również sprawę z generalizacji w opisie pomijającym wewnątrzkulturowe zróżnicowanie polskiej wsi (s. 20). Uwagę koncentruje na czterech polach badawczych: rodzinie, ciele, pracy i śmierci. Każdy z analizowanych przez nią obszarów przynosi po kilka przykładów „swoich obcych” osadzonych w kulturze ludowej i reprezentowanych w licznie przywoływanych przekazach folklorystycznych. W rezultacie poszczególne rozdziały omawianej książki są pojemne treściowo i przedstawiają kolejno: 1. stare panny i kawalerów, panny z dzieckiem, dzieci nieślubne, sieroty, macochy, niedołężnych krewnych; 2. kowali, młynarzy, muzykantów oraz tzw. mądrych/mądre; 3.dzieci zmarłe bez chrztu lub abortowane oraz samobójców. Warto w tym miejscu zauważyć, że niektóre rozdziały lub podrozdziały tej część książki zostały zatytułowane w stylistyce metaforycznej (np. Niebiański protektorat; W objęciach grzechu; Samobójca w szponach diabła), co może wywoływać zróżnicowane reakcje czytelników.

Zadurska deklaruje dynamiczne podejście do rozważanych kwestii. O ile idea ta jest dobrze wyjaśniona w perspektywie negatywnej - to znaczy wiemy, z czym nie będziemy mieli do czynienia w prezentowanych rozważaniach o tyle jej eksplikacja pozytywna nie wskazuje zbyt jasno, o jaki dynamizm czy o jakie dynamizmy w istocie chodzi. W kilku miejscach pracy autorka próbuje

1 Na temat różnych sposobów prezentacji obcych por. m.in. Kalniuk 2015: 312-329. 
tłumaczyć przyjmowane stanowisko jako niebinarne, a zarazem przedkładające rolę czynnika świadomościowego ponad odgórnie przypisanymi wyznacznikami etnicznymi, kulturowymi, językowymi czy religijnymi (s. 17-18, 31-32, 237). Niestety wzmianki dotyczące tych kwestii są niewystarczające i wymagałyby rozwinięcia. Próba wydobycia subiektywnych sensów kulturowych, odwołująca się do współczynnika humanistycznego (propozycja Floriana Znanieckiego) czy relatywizmu kulturowego (szkoła Franza Boasa) wymaga choćby skrótowego zaznajomienia odbiorcy z szerszym kontekstem społeczno-kulturowego obrazu wsi. W przeciwnym wypadku ryzykuje się skazaniem czytelnika na domysły i pomyłki. Nie wiadomo np., czym są nietypowe standardy odpowiedzialne za stygmatyzacje albo czy w ślad za stwierdzeniem o odgórności czynników etnicznych idzie też przeświadczenie autorki o represyjnym charakterze kultury? Założenie powszechnej znajomości znaczeń kulturowych określających obcość jest błędem i ogranicza grupę potencjalnych odbiorców pracy. Dlatego albo należałoby przemyśleć i przebudować w monografii rozdział Obcy wśród swoich na tle problematyki obcości w kulturze ludowej, albo przynajmniej precyzyjniej wyrazić zamysł autorski. W obecnym kształcie mamy bowiem do czynienia z zachodzeniem na siebie dość odległych koncepcji rozumienia zjawisk kulturowych - symbolicznej i behawioralnej. Dodatkowo niechęć do ujęcia normatywnego łączy się tu z chęcią wskazania reguł odpowiedzialnych za stygmatyzację niektórych spośród członków grupy, która zresztą nie zostaje należycie zrealizowana.

Naznaczeni od Pana Boga nie aspirują do rangi pozycji z finalnym rozstrzygnięciem kwestii rozważanych w antropologii od dekad (i w dużej mierze dla niej konstytutywnych). Stwierdzenie to nie jest bynajmniej równoznaczne z przypisaniem pracy charakteru przyczynkarskiego. Autorka, stawiając sobie za cel rekonstrukcje wyobrażeń o obcych, ujawnia spore ambicje. Choć dystansuje sie od zawiłych koncepcji poznawczych typowych dla strukturalistów, to - podobnie jak oni - dąży do odkrycia prawidłowości kierujących ludzkim myśleniem i odpowiedzialnych za procesy społecznej stygmatyzacji. Szczęśliwie jednak jej zainteresowanie kwestiami reguł i procesów mentalnych pozostaje na poziomie deklaracji, a sprawom tym nie poświęcono w pracy szczególniejszej uwagi. To niedopowiedzenie stanowi, paradoksalnie, szczęśliwy brak, chroniący wywód przed zawilymi dywagacjami i konstruowaniem neoscjentystycznych modeli na wzór dokonań Claude’a Lévi-Straussa czy Władimira Proppa, by wspomnieć tylko reprezentantów etnologii i folklorystyki, czyli dyscyplin, których narzędzia Zadurska wykorzystuje do rekonstrukcji obrazu obcych. Bardziej adekwatne zatem wydaje się przypisanie omawianej monografii funkcji uzupełniającej dotychczasowy korpus wiedzy. Oryginalnym wkładem autorki do tych badań jest zaś egzemplifikacja takich odmian obcości, które znajdowały się w pobliżu granic ludowego świata.

Pisząc książkę o obcych, Zadurska prezentuje perspektywe „ubogiego innego”, w swoich rozważaniach oddając głos osobom społecznie zmarginalizowanym. Czyni to lekko i niejako przy okazji głównej wypowiedzi, a zarazem bez popu- 
larnego ostatnio polemicznego zacięcia, przybierającego postać literatury rozliczeniowej. Autorka ma bowiem świadomość ambiwalencji obcych, co ilustruje odpowiednimi przykładami, ukazującymi ich zarówno w roli wybrańców, jak i ukaranych przez Boga nieszczęśników (s. 59, 73, 178). Lektura Naznaczonych od Pana Boga, choć z założenia wychylona w partykularną przeszłość, dostarcza również materiału do refleksji o charakterze bardziej uniwersalnym i aktualnym. Wskazane przez badaczkę przykłady współczesnych kulturowych, filmowych i literackich postaci obcych nasuwają skojarzenia z koncepcją archetypów i prowokują pytania o trwałość przejawów myślenia mitycznego, a w polskim kontekście zmuszają do namysłu nad ludowym dziedzictwem oraz skalą i sposobem jego funkcjonowania w czasach współczesnych. Wiadomo przecież, że chłopi okazali się tą grupą społeczną, która w porównaniu z innymi odniosła relatywnie najmniejsze straty w okresie wojen i niewoli. Można się więc zastanawiać, czy jej powojenna dominacja w demograficznej strukturze narodu polskiego nie wywarła też istotnego wpływu na jego sferę mentalną, poprzez kształtowanie określonych nawyków myślowych oraz składników społecznego imaginarium, w tym również wyobrażeń na temat obcych (por. Robotycki, Węglarz 1983; Wasilewski 2012).

\section{BIBLIOGRAFIA}

Kalniuk, T. (2015). Symbolic Migrationstothe Super Westin Polish Pomeranian Pressfrom 193os. In D. Demski, L. Laineste, K. Baraniecka-Olszewska (eds.), War Matters. Constructing Images of the Other (1930s to 1950s) (s. 312-329). Budapest: Editions L'Harmattan.

Robotycki, C., Węglarz, S. (1983). Chłop potęgą jest i basta. O mityzacji kultury ludowej w nauce. Polska Sztuka Ludowa, 37(1-2), 3-8.

Wasilewski, J. S. (1980). Podarować - znaleźć - zgubić - zbłądzić. Niektóre kategorie języka symbolicznego związane z opozycją życie-śmierć. Etnografia Polska, 24(1), 283-303.

Wasilewski, J., Duch-Dyngosz, M. (2012, maj). Jesteśmy potomkami chłopów. Z Jackiem Wasilewskim rozmawia Marta Duch-Dyngosz. Znak, 5 [wydanie internetowe]. Pobrano z: http:// www.miesiecznik.znak.com.pl/6842012z-prof-jackiem-wasilewskim-o-genealogii-polskiegospoleczenstwa-rozmawia-marta-duch-dyngoszjestesmy-potomkami-chlopow/

Wróblewska, V. (2011). Od bohatera mitycznego do bohatera bajkowego (na przykładzie opowieści ludowych). W: P. Kowalski (red.), Mit, prawda, imaginacja (s. 145-156). Wrocław: Wydawnictwo Uniwersytetu Wrocławskiego.

Zowczak, M. (1991). Bohater wsi - mit i stereotypy. Wrocław: Wydawnictwo Wiedza o Kulturze. 